\title{
DIPLOMASI TINGKAT TINGGI: SEBUAH PEMAHAMAN AWAL
}

\author{
Z u l k a r n a i n \\ (Dosen FISIP Program Studi Hubungan Internasional Universitas Nasional Jakarta, \\ mahasiswa Doktoral Ilmu Hubungan Internasional Program Pascasarjana FISIP- \\ Universitas Padjadjaran Bandung) \\ zulkarnainbolak@yahoo.com
}

\begin{abstract}
ABSTRAK
Diplomasi tingkat tinggi adalah milik kepala negara atau kepala pemerintahan. Akan terjadi bila terdapat permasalahan krusial yang dihadapi oleh negara-negara yang bersangkutan dan secara langsung menyentuh kepentingan kolektif dua atau lebih negara yang terlibat di dalam pertemuan tingkat tinggi tersebut. Diplomasi tingkat tinggi juga merupakan refleksi dari sebuah respon cepat para pihak yang cenderung menghasilkan agenda yang berbobot, sehingga diplomasi tingkat tinggi bukanlah rangkaian kegiatan kepala negara atau kepala pemerintahan yang penuh dengan misi pencitraan, melainkan adalah misi penting untuk kepentingan nasional. Satu hal yang teramat penting dari diplomasi tingkat tinggi adalah "idiologi" dari diplomasi tingkat tinggi itu sendiri, yakni penyusunan strategi, koordinasi dan langkah-langkah implementatif yang ditujukan pada pencapaian target dan tujuan. Dengan begitu, diplomasi tingkat tinggi terhindar dari hembusan angin yang berlalu tanpa kesan berarti bagi umat manusia.
\end{abstract}

Kata kunci : diplomasi, diplomasi tingkat tinggi, kepentingan nasional

\begin{abstract}
Summit diplomacy belongs to the head of state or head of government. It will happen when there are crucial problems faced by the countries concerned and directly touch the collective interests of two or more countries involved in the summit. Summit or high-level diplomacy is also a reflection of a quick response by the parties that tends to produce a weighted agenda, so high-level diplomacy is not a series of activities of heads of state or heads of government filled with imaging missions, but rather an important mission for the national interest. One of the most important things of high-level diplomacy is the "ideology" of high-level diplomacy itself, namely the preparation of strategies, coordination and implementation measures aimed at the achievement of targets and objectives. That way, summit diplomacy avoids the blowing winds that pass without meaningful impression to mankind.
\end{abstract}

Key words : diplomacy, summit diplomacy, national interest

\section{Latar Belakang}

Dalam berbagai pemberitaan politik internasional di media massa, sering kali kita disuguhkan oleh peristiwa-peristiwa internasional yang memuat adanya pertemuan-pertemuan antar kepala negara atau kepala pemerintahan di sebuah 
tempat tertentu. Seperti yang pernah dilakukan oleh Presiden AS dengan pemimpin Palestina dan Israel yang membahas agenda-agenda perdamaian. Kemudian pertemuan kepala negara atau kepala pemerintahan yang tergabung dalam negaranegara G7 atau G8 atau G20 yang membahas masalah ekonomi, keuangan dan perdagangan internasional. Pertemuan tingkat tinggi negara-negara Asia-Afrika yang kerap membahas masalah-masalah sosial ekonomi dan pembangunan atau pertemuan tingkat tinggi dalam skala yang lebih global seperti Konferensi Tingkat Tinggi bidang Lingkungan Hidup yang membawa agenda lingkungan hidup global.

Pertemuan tingkat tinggi antar kepala negara atau kepala pemerintahan tersebut merupakan salah satu fenomena penting dalam kajian hubungan internasional. Fenomena ini mengemuka seiring dengan terjadinya berbagai perubahan atas tata politik internasional. Pertemuan tingkat tinggi adalah sisi penting dalam sejarah politik internasional yang dinilai turut mendorong terciptanya tata keamanan dan perdamaian dunia. Berbagai aktifitas pertemuan tingkat tinggi bahkan dikategorikan sebagai instrumen utama jalur diplomasi yang dinilai efektif menyelesaikan berbagai permasalahan dunia, terutama sekali permasalahan yang menyangkut pada dimensi keamanan internasional. Secara nyata hal ini dapat dilihat pada masa perang dingin. Bahkan saya cenderung meyakini bahwa konferensi atau pertemuan tingkat tinggi telah menjadi variabel penting yang turut mendorong terciptanya perdamaian atau tidak adanya perang terbuka antara dua kekuatan besar (AS-US) selama masa perang dingin berlangsung. Dengan demikian, pertemuan tingkat tinggi sangat terkait dengan pilihan-pilihan strategis politik luar negeri sebuah negara untuk menghadapi dan menyelesaikan masalah-masalah internasional, terutama masalah internasional yang dianggap krusial.

Peristiwa-peristiwa internasional yang ditandai dengan adanya pertemuanpertemuan antar kepala negara atau kepala pemerintahan tersebut adalah fakta empirik yang sesungguhnya dapat dipelajari dan dipahami melalui kajian teoritis dalam studi hubungan internasional. Sebagai pengetahuan awal, apa sajakah yang patut diketahui tentang fenomena pertemuan-pertemuan antar kepala negara atau kepala pemerintahan tersebut dalam perspektif teori hubungan internasional ?

\section{Tinjauan Etimologis}

Pertemuan antar kepala negara atau kepala pemerintahan dalam sebuah peristiwa internasional tertentu sering kali diistilahkan dengan sebutan Konferensi Tingkat Tinggi, Pertemuan Tingkat Tinggi atau Pertemuan Puncak. Dalam pemahaman sehari-hari, istilah-istilah tersebut seringkali digunakan secara bersamaan. Pada dasarnya istilah-istilah ini memang tidaklah berbeda, ketiganya merupakan bagian integral dari studi diplomasi dalam kajian ilmu hubungan internasional. Kalaupun terdapat perbedaan, maka perihal teknis menyangkut jumlah peserta yang mengikuti kegiatan, adalah aspek utama yang membedakannya. Konferensi tingkat tinggi, pesertanya diikuti oleh para elit politik (kepala negara atau kepala pemerintahan) dalam jumlah yang lebih banyak, yaitu empat atau lebih elit politik. Sedangkan pertemuan tingkat tinggi dan pertemuan puncak biasanya diikuti oleh jumlah peserta yang terdiri dari dua hingga tiga orang elit politik saja (kepala negara atau kepala pemerintahan). Namun demikian secara substansial konferensi atau pertemuan tingkat tinggi dan pertemuan puncak merupakan 
terminologi-terminologi yang memiliki banyak kesamaan, antara lain adalah; Pertama; aspek pesertanya hanya terdiri dari atau diikuti oleh elit politik dan pemerintahan pemegang kekuasaan eksekutif tertinggi negara yang bersangkutan saja. Kedua; agenda yang dibicarakan termasuk dalam kategori khusus, penting, mendesak dan dianggap memiliki status yang membutuhkan penyelesaian secara cepat. Ketiga; berorientasi dan lebih diprioritaskan kepada pencapaian keputusan dalam pelaksanaan negosiasinya, Keempat; merupakan pertemuan atau konferensi yang sebenarnya hanya "tinggal mengetuk palu" saja agar menjadi sah sebagai sebuah keputusan bersama, karena sebelumnya telah dikondisikan melalui pertemuan-pertemuan sejenis pada tingkat kementerian dan atau pada tingkat pakar. Lebih dari itu -sekaligus yang kelima- sudut pandang paradigmatik juga turut menempatkan adanya kesamaan antara konferensi tingkat tinggi di satu sisi dengan pertemuan tingkat tinggi dan pertemuan puncak di sisi lain. Ketiganya dihampiri lewat perspektif studi diplomasi yang tergolong ke dalam kategori summit diplomacy.(Hamilton and Langhaorne, 1995; 155). Menurut pandangan para American Scholars, terminologi summit diplomacy atau diplomasi pertemuan tingkat tinggi ini mulai masuk dan berkembang dalam vocabulari politik internasional sejak tahun 1950-an.

\section{Diplomasi Tingkat Tinggi}

Istilah Diplomasi Tingkat Tinggi (summit diplomacy) muncul bersamaan dengan adanya peningkatan ketegangan dunia yang diperankan oleh negara-negara super power pada era perang dingin. Atas dasar kuatnya keinginan untuk menata struktur keamanan dunia kepada posisi yang lebih baik pada masa itu, maka muncul inisiatif perlunya pertemuan tingkat tinggi antar kepala negara atau kepala pemerintahan. Terminologi pertemuan tingkat tinggi (summit) atau diplomasi tingkat tinggi diperkenalkan oleh PM Inggris Sir Winston Churchill dalam sebuah kesempatan ketika pemilu berlangsung di negara tersebut pada Februari 1950. Churchill menyebutnya dengan "parley at the summit" as a means of easing and overcoming East-West tensions. (Hamilton and Langhaorne, 1995; 221). Churchil melontarkan gagasan ini ketika Inggris sedang aktif dalam mengelola perang dingin antara blok Barat dan blok Timur. Gagasan Churchill ini kemudian dilangsungkan dengan adanya beberapa kali putaran pertemuan antara pemimpin dari pihak Barat (AS, Inggris dan Prancis) dengan pemimpin dari pihak Timur (Uni Soviet). Pertemuan-pertemuan tingkat tinggi yang dilakukan oleh para pemimpin kedua blok kekuatan dunia antara tahun 1950 hingga 1960, merupakan bagian penting dari praktek summit diplomacy. Gagasan Churchil ini diambilnya dari pengalaman para pemimpin Eropa dan AS sebelumnya yang pada saat itu aktif mengelola dan mengakhiri perang dunia kedua. Beberapa pertemuan tingkat tinggi seperti pertemuan Teheran (1943), Yalta (1945) dan Postdam (1945) yang pernah dilakukan oleh elit-elit pemerintahan dari negara-negara inti tadi, merupakan inspirasi baginya sekaligus menjadi salah satu bukti penting pelaksanaan diplomasi tingkat tinggi.

Status dan keadaan saat perang dingin yang diwarnai oleh keteganganketegangan, telah menjadi motif utama bagi perlunya diselenggarakan pertemuan tingkat tinggi. Kepala negara atau kepala pemerintahan yang mewakili negaranegara kuat tadi, telah bertindak sebagai aktor penting pada masa perang dingin. Hal 
ini sesuai dengan apa yang dikemukakan oleh Berridge, bahwa ... in mid-century, when the wartime conferences of the big three -Roosevelt, Churchill and Stalinwere its centerpiece. (Berridge, 1995; 79).

Dalam perkembangan berikutnya, seiring dengan terjadinya perubahan dan transformasi sistem internasional, model yang diusulkan Churchill ini banyak diadopsi oleh pihak-pihak lain atau kelompok-kelompok elit tertentu, sehingga summit atau pertemuan yang diikuti oleh elit politik dari kalangan eksekutif (kepala negara atau kepala pemerintahan) tersebut menjadi berkembang ke arah yang lebih luas. Perkembangan ini tidak hanya terbatas pada jumlah peserta yang ikut, melainkan juga menyentuh pada ruang lingkup agenda yang dibicarakan. Vandana mengakui bahwa status summit yang sebelumnya hanya memiliki latar belakang perang dan penciptaan tata keamanan dunia, telah mengalami perkembangan signifikan pada tahun-tahun berikutnya. Isu yang tadinya berkisar pada masalahmasalah keamanan global, mengalami perubahan kepada isu-isu lain yang lebih bersifat low-politics. Aktor-aktor summit yang sebelumnya lebih banyak melibatkan negara-negara super power, tidak lagi dominan dalam berbagai aktifitas summit internasional, melainkan telah melibatkan banyak aktor dari berbagai kawasan dunia. Salah satunya menurut Vandana sebagai contoh adalah pertemuan tingkat tinggi negara-negara Asia Afrika. Vandana menyebutkannya dengan menegaskan bahwa meetings of Asian and African heads of states and Prime Minister in Bandung, in 1955 at the Asian-African Conference, Non-Aligned Conference of states since 1961 onwards are examples of summit diplomacy (Vandana, 1996; 145). Dengan demikian, istilah summit pada prinsipnya digunakan untuk melihat dimensi pertemuan tingkat tinggi atau konferensi internasional.

Sekalipun istilah summit baru muncul dan berkembang pada pertengahan tahun 1950-an, kondisi serupa sebenarnya sudah pernah terjadi dalam sejarah diplomasi internasional pada tahun-tahun sebelumnya. Hamilton dan Langhorne, mempertegasnya dengan menyatakan bahwa sebelum kemajuan perkembangannya pada tahun 1950-an, summit diplomacy sudah pernah dilakoni oleh beberapa elit politik negara-negara di daratan Eropa (Hamiliton and Langhorne, 1995; 136-182). Dalam sejarah praktek diplomasi, periode antara abad ke 18 hingga permulaan abad ke 20 adalah saat-saat penting untuk menyaksikan betapa praktek diplomasi sejenis summit ini pernah terjadi. Serangkaian kesepakatan-kesepakatan yang dihasilkan dari Congress of Vienna (1815), yang sekaligus mengakhiri perang Napoleon di Eropa, adalah salah satu produk penting yang tidak terpisahkan dari peran summit diplomacy. The Paris Peace Conference (1919-1920) yang merupakan embrio bagi lahirnya Liga Bangsa-Bangsa adalah bagian penting lainnya yang tidak dapat dilepaskan dari peran summit diplomacy. Maurice Hankey, the Secretary of the British War Cabinet dalam periode itu mengatakan bahwa hasil-hasil yang dicapai dari The Paris Peace Conference adalah bagian tidak terpisahkan dari "diplomacy by conference". Seterusnya dijelaskan pula bahwa this is the conduct of intergovernmental relations by "direct and frequent consultations between the principal Ministers concerned". It was in many respects a perpectly natural development in wartime, when decisions had to be taken quickly by allied governments (dalam Hamiliton and Langhorne, 1995; 145). Dari penjelasan Hankey ini, ditemukan bahwa praktek diplomasi sejenis summit adalah bagian penting yang dapat 
menghasilkan beberapa keputusan-keputusan penting menyangkut pengelolaan permasalahan Eropa, terutama pada awal abad ke 20.

Jauh sebelum antara abad ke 18 hingga awal abad ke 20, sebagaimana cuplikan penjelasan singkat di atas, praktek diplomasi serupa (summit) ternyata sudah pernah pula hadir menghiasi studi dan sejarah diplomasi internasional. Bahkan secara jelas Hamilton dan Langhorne mengurai praktek-praktek diplomasi sejenis summit ini pada era menjelang abad pertengahan dalam satu bab dari buku yang ditulisnya. Di dalam buku itu dijelaskan bahwa diplomasi sejenis ini banyak dipraktekkan oleh kalangan raja-raja atau para pemimpin kerajaan pada masa Yunani, Romawi, Byzantium dan masa kejayaan bangsa-bangsa Arab hingga pada abad pertengahan (Hamiliton and Langhorne, 1995; 7-28). Terkait dengan praktek diplomasi sejenis summit yang banyak digunakan menjelang abad pertengahan ini, Queller menyebutnya dengan istilah nuncius. Menurutnya, nuncius adalah conveyed the will of his principal and could not act upon his own will so as to commit his principal. He could negotiate conventions in the form of a draft, but these could not be made obligatory upon the principal without their referral to him and an expression of his will to be bound. Whatever a nuncius could do was conceived to be done directly by the principal. (Queller, 1967; 225). The use of the nuncius was intended to lead either, and most likely to a meeting of their minds through a last exchange of nuncii. "Summit meetings" were more usual in an age where most diplomatic relationships were with neighbours, and they were occasions so fraught with anxiety about both the fisical safety of the rulers concerned and the exact rectitude of the ceremonial involved, that specially constructed meeting places were often arranged, if possible precisely on a border - a bridge, or on a barge on a riverand surrounded with protective devices such as wooden lattice work in order to remove the risk of physical violence or abduction. (Hamiliton and Langhorne, 1995; 26). Dari uraian-uraian di atas jelaslah bahwa terminologi diplomasi summit, sebenarnya bukanlah istilah baru dalam studi diplomasi, melainkan istilah lama yang telah pernah ada semenjak praktek diplomasi itu sendiri muncul.

Masih dalam konteks ini, Queller mengatakan bahwa summit adalah bagian dari studi diplomasi dan summit diplomacy adalah diplomatic relations were largely confined to neighbouring states (Queller, 1967; 225). Berridge, mengatakan bahwa summit merupakan bagian dari diplomasi multilateral dan atau bilateral yang dilakukan oleh pihak-pihak yang berada pada level tertinggi dari sebuah pemerintahan negara, yaitu antara pemimpin negara atau kepala pemerintahan. Pertemuan tingkat tinggi ini dilakukan untuk membahas masalah-masalah khusus yang dinilai mendesak untuk dibicarakan karena menyangkut berbagai kepentingan nasional dan kepentingan global (Berridge, 1995; 78). Secara lebih khusus, Berridge membagi summit diplomacy ini ke dalam tiga jenis pertemuan tingkat tinggi, yaitu serial summits, ad-hoc summits dan the high-level exchange of views. Menurut Berridge, serial summits menyangkut pada ... frequent or separated by a year or more, and whether they last for hours or days, they may contribute to a successful negotiation between the parties concerned for one or more of the following reasons. (Berridge, 1995; 85). Sedangkan ad-hoc summits menyangkut pada ... summit meeting in negotiation is to some extent a function of its length -the longer the better. (Berridge, 1995; 88). Seterusnya jenis the high-level "exchange of views" 
menyangkut pada ... the educational argument for this kind of summitry is a strong one, though perhaps more in friendly relationships than adversary ones ... its more modest ambitions and generally relatively low-key proceedings, the "exchange of views" summit is probably best suited of all summits to promoting friendly relations ... exchange of views summit is necessarily better at clarifying intentions and gathering information than the serial summit or even the average ad hoc summit. (Berridge, 1995; 91).

Berikutnya adalah pandangan Eubank, ia menyebutkan bahwa summit merupakan bagian dari diplomasi yang dilakukan oleh dua atau lebih pemimpin negara atau kepala pemerintahan yang bertujuan untuk menghasilkan keputusankeputusan penting yang dilakukan secara cepat dalam rangka mengatasi berbagai permasalahan penting yang dihadapi oleh negara-negara terkait.(Eubank,1966; 5). Dalam pandangan lain, Vandana menjelaskan bahwa summit adalah bagian dari diplomasi dan bahkan memasukkan summit diplomacy ini sebagai salah satu tipe diplomasi dari tipe-tipe yang menurutnya terdiri dari 7 (tujuh) bagian, yaitu democratic diplomacy, multilateral diplomacy, summit diplomacy, coalition diplomacy, commercial diplomacy, cultural diplomacy, and shopkeeper diplomacy-warrior diplomacy. (Vandana, 1996; 144-146).Menurutnya, summit diplomacy adalah diplomacy at the highest level is an ancient practice. (Vandana, 1996; 145). Kemudian dalam pengertian yang sederhana, Hamilton dan Langhorne menyebutkan bahwa summit diplomacy adalah consultation amongs political leaders. (Hamilton and Langhorne, 1995; 234). Konsultasi yang dilakukan oleh para peserta pertemuan tingkat tinggi itu mempunyai agenda-agenda tertentu yang sebelumnya telah dikaji dan dirumuskan oleh para peserta pertemuan sebelum kepala negara atau kepala pemerintahan masing-masing negara. Forum konsultasi ini bertujuan menghasilkan berbagai keputusan setelah didahului oleh pertemuanpertemuan sebelumnya. Pertemuan-pertemuan sebelumnya ini dilakukan oleh pertemuan setingkat menteri dan atau setingkat pakar atau pertemuan setingkat misi khusus.

Lalu mengapa di dalam summit itu hanya melibatkan kepala negara atau kepala pemerintahan saja ? Menurut Ball, terdapat beberapa pertimbangan mendasar untuk menjawab pertanyaan tersebut, yaitu; Pertama, karena kepala negara atau kepala pemerintahan adalah orang yang dinilai memiliki otoritas politik sehingga memiliki kewenangan penuh untuk mewakili rejim pemerintahannya dan atau negaranya. Keputusan-keputusan yang diambil oleh kepala negara atau kepala pemerintahan sekaligus juga dinilai sebagai kehendak-kehendak bersama masyarakat atau rakyat dari negara yang diwakilinya. Kedua, kepala negara atau kepala pemerintahan dianggap sebagai orang yang banyak mengetahui lebih detil berbagai permasalahan-permasalahan dunia yang dihadapi. Ketiga, karena pertemuan yang dihadiri kepala negara atau kepala pemerintahan dinilai mempunyai legalitas dan kekuatan hukum, oleh karena itu pertemuan tingkat tinggi yang diselenggarakan sangat kecil kemungkinan menemui jalan buntu atau gagal. Keempat, karena kepala negara atau kepala pemerintahan memiliki keperdulian yang tinggi atas permasalahan-permasalahan yang dihadapi, apalagi permasalahan itu menyangkut pada kelangsungan hidup bangsa, kemajuan dan pembangunan serta 
berbagai permasalahan sosial ekonomi lainnya. Kelima, karena kepala negara dan kepala pemerintahan merupakan pejabat publik maka mereka cenderung memiliki daya publik sehingga apapun yang dihasilkan sebagai produk tingkah lakunya sangat berpeluang besar untuk implementatif pada tingkat operasional. (Ball, 1982; 427).

Kelima asumsi di atas merupakan alasan-alasan yang dikemukakan Ball menyangkut pentingnya sebuah forum dihadiri oleh kepala negara atau kepala pemerintahan. Intinya adalah bahwa keikutsertaan kepala negara atau kepala pemerintahan dalam sebuah forum pertemuan tingkat tinggi akan mempermudah pencapaian kepentingan-kepentingan nasional negaranya masing-masing.

Namun dalam pandangan lain, disebutkan bahwa pertemuan tingkat tinggi sebenarnya bisa saja menemui jalan buntu dan serangkaian kegagalan sehingga pertemuan tingkat tinggi itu menjadi sia-sia. Dalam diplomasi pertemuan tingkat tinggi, kebuntuan atau kegagalan ini ditandai dengan beberapa indikator, antara lain; (Berridge, 1995; 79-80).

- Agreements which are inconsistent with or irrelevant to their national interest.

- Conclude no agreement at all.

- Out of ignorance of the detail of the issue under discussion.

- Inadequate time (summits have to be brief and much of the time is usually taken up with protocol function).

- Failure to understand nuances in the position of the other side (especially if there is a cultural divide).

Selanjutnya, mengapa kebuntuan atau kegagalan sebagaimana tertera di atas dapat terjadi ? Beberapa ahli melihat bahwa kebuntuan atau kegagalan pertemuan tingkat tinggi bisa terjadi karena faktor sikap dan perilaku kepala negara atau kepala pemerintahannya sendiri. Karakter elit politik yang menjadi peserta dalam setiap pertemuan tingkat tinggi, dinilai menjadi determinan penting untuk melihat gagal atau berhasilnya summit itu. De Magalhaes mengungkapkan bahwa kebuntuan atau kegagalan bisa terjadi karena faktor sikap dan karakter kepala negara atau kepala pemerintahannya sendiri. Lebih jelasnya ia mengemukakan bahwa kebuntuan dan kegagalan itu ... may also occur because heads of government develop either personal like or dislikes for their interlocutors, because they are fearful that enjoyment of generous hospitality may lead a tough bargaining position to be construed as bad manners ...(De Magalhaes, 1988; 55). Pendapat lain dikemukakan oleh Eubank, ia menyebutkan bahwa kegagalan atau kebuntuan dari sebuah pertemuan tingkat tinggi dapat terjadi, because they get carried away by the atmosphere -the theatre- of the occasion, or because they fall ill ....(Eubank,1966; 205). Aspek-aspek lain yang membuat pertemuan tingkat tinggi itu mengalami jalan buntu atau gagal adalah sebagaimana yang dikemukakan oleh Watt, ia menegaskan bahwa ... heads of government, with their massive egos, their ignorance of the essential details and their ingrained belief in the value of back-slapping ambiguity ...(dalam Berridge, 1995; 81).

Berdasarkan pendapat-pendapat para ahli di atas, maka faktor-faktor yang dinilai dapat membuat sebuah diplomasi pertemuan tingkat tinggi menemui jalan buntu atau mengalami kegagalan adalah sebagai berikut. Pertama, terkait dengan karakter individu kepala negara atau kepala pemerintahan yang mengikuti 
pertemuan tingkat tinggi itu. Kedua, terkait dengan latar belakang fakta sosial yang berkembang pada saat pertemuan tersebut berlangsung. Ketiga, terkait dengan kemampuan serta pengetahuan dan tingkat wawasan para peserta pertemuan dalam menguasai agenda dan permasalahan yang tengah dihadapi. Keempat, terkait dengan hal-hal teknis, seperti kelayakan persidangan, kenyamanan peserta, nuansa pertemuan dan lain-lain yang mendukung kegiatan pertemuan tingkat tinggi itu.

\section{Simpulan}

Beberapa penjelasan tentang terminologi pertemuan atau konferensi tingkat tinggi seperti yang sudah diuraikan di atas, pada dasarnya telah memicu kita untuk dapat lebih memahami makna sekaligus memahami serangkaian aspek yang berada di sekitar konsep pertemuan atau konferensi tingkat tinggi itu. Pandanganpandangan para ahli tersebut telah memberikan suatu pemahaman awal bagi kita sebagai penstudi hubungan internasional, bahwa pertemuan tingkat tinggi (summit) ternyata tidak sesederhana yang dibayangkan. Tetapi paling tidak dapat disimpulkan bahwa summit atau pertemuan tingkat tinggi sudah sejak lama dipraktekkan oleh para kepala negara atau kepala pemerintahan. Perkembangan summit tidak terlepas dari dinamika dan fenomena sosial (social setting) yang melatarbelakanginya. Intinya, fenomena sosial yang terjadi pada saat itu ternyata turut mendorong dan memberi bobot bagi munculnya pertemuan atau konferensi tingkat tinggi. Kemudian dapat pula disimpulkan bahwa summit atau pertemuan tingkat tinggi adalah bagian dari studi diplomasi yang didalamnya mencakup kegiatan interaksi yang meliputi negosiasi dan konsultasi antar kepala negara atau kepala pemerintahan dalam rangka mencari jalan keluar atas berbagai permasalahan-permasalahan krusial yang dihadapi oleh negara-negara.

Summit atau pertemuan tingkat tinggi ini dilaksanakan atas dorongan yang kuat untuk memecahkan permasalahan secara cepat. Summit atau pertemuan tingkat tinggi adalah juga rangkaian kegiatan diplomasi yang berlangsung setelah sebelumnya menyelesaikan pembahasan substansi materi atau draft materi pada tingkat menteri dan tingkat pakar sesuai bidang pembahasan. Kemudian patut diketahui pula bahwa summit dapat berakhir dengan kegagalan atau keberhasilan.

Seterusnya, kesimpulan lain dapat disampaikan bahwa prinsip dan orientasi diplomasi summit sebenarnya bukanlah terletak pada out-put, melainkan pada proses pelaksanaan dan keberlangsungannya. Oleh sebab itu summit sangat tergantung kepada sejauhmana tingkat krusial agenda yang dipermasalahkan. Kemudian perlu disampaikan juga bahwa summit bukan berarti aktifitas diplomasi yang hanya terbatas pada satu kali momentum saja, melainkan adalah diplomasi yang berangkai dan berkelanjutan sehingga upaya dan penyusunan strategi, koordinasi kebijakan serta langkah-langkah implementatif yang ditujukan pada pencapaian target dan tujuan, adalah "idiologi" dari summit itu sendiri. Sekali lagi idiologi summit ini hanya akan terwujud bila mana masalah-masalah itu adalah masalah krusial dan secara langsung menyentuh kepentingan kolektif semua negara yang terlibat di dalam pertemuan tingkat tinggi tersebut serta semua negara di luar peserta pertemuan atau konferensi tingkat tinggi itu. 


\section{Daftar Pustaka}

A., Vandana, Theory of International Politics, (Vikas Publishing House, New Delhi, 1996)

Acheson, Dean, Present at the Creation; My Years in the State Department, (Norton; New York, 1969)

Ball, George, The Past Has Another Pattern, (Norton; New York, 1982)

Berridge, G.R., Diplomacy; Theory and Practice, (Prentice Hall-Harvester Wheatsheaf; London-NY, 1995)

De Magalhaes, J.C., The Pure Concept of Diplomacy, (Greenwood; New York, 1988)

Eubank, K., The Summit Conferences 1919-1960, (University of Oklahoma Press; Norman, Oklahoma, 1966)

Hamilton, Keith and Richard Langhorne, The Practice of Diplomacy; Its Evolution, Theory and Administration, (Routladge; London and New York, 1995)

Nicholson, Harold, The Evolution of Diplomatic Method, (Oxford; New York, 1954)

Queller, D.E., The Office of Ambassador in the Middle Ages, (Princeton; New Jersey, 1967) 
